\title{
A SKETCH OF NGEN PHONOLOGY
}

\author{
Tatiana Korol \\ Institute of Linguistics RAS \\ bomolopuu@gmail.com
}

Abstract: The paper provides a preliminary description of the phonology of Ngen, a South Mande language spoken in Ivory Coast. Ngen has a system of oral and nasal vowels. The consonant inventory is characterised by a complementary distribution between [b] and [m], [l] and [n], [y] and [n]. There are 3 level tones. Tone melodies on disyllabic feet exhibit all possible combinations except LH. The majority of nonderived words have CV, CVCV, and CV $\eta$ structures.

Key words: Ngen, South Mande, phonology

\section{Introduction}

Ngen (South Mande < South-East Mande < Mande < Niger-Congo) is a minority language of Ivory Coast. The closest relative of Ngen is Beng (Paperno 2014). According to my comparison of vocabulary in the Swadesh list, Beng and Ngen have 27-36\% of difference; Gban and Ngen have 50-58\% of difference; Mwan and Ngen have 54-55\% of difference; Wan and Ngen have 60-64\% of difference.

Most of the Ngen ethnic population lives in the village of Djonkrou, which is located in the prefecture of Prikrou towards the east of the center of Ivory Coast. The population of Djonkrou village is close to 1500. However, according to Maloletnjaja (2015), only 765 inhabitants are speakers of Ngen. In the northwest of Djonkrou, there is a village of Mangofla where, according to my consultants, there are approximately 200 Ngen speakers. There is also a Ngen diaspora in Abidjan, which encompasses around 100 people. Thus, the number of Ngen speakers is currently close to 1000 . 
The present paper is based on materials from the thesis of Anna Maloletnjaja (2015) and my own data recorded during a field trip in 2019, together with Valentin Vydrin. I worked with Kouassi Makaman Koffi (or Sualio Wattara, 41 y.o. at the time of the recording) who is an inhabitant of the Djonkrou village. The present sketch is based on approximately 2000 words and phrases. All the examples provided in this paper have been verified in field trip of 2021 with my second language assistant Kouadio Kouadio Yacouba (43 y.o.), who lived in Djonkrou before his marriage, then moved to Abidjan.

Here are the main typological characteristics of Ngen:

- 3 level tones (tonal rules require further research)

- nasal harmony on the foot (cf. §5.1)

- strict Subject-Auxilary-Object-Verb-X (other components) word order

- dependent noun precedes head noun in possessive constructions: $\mathrm{N}_{\mathrm{GEN}} \mathrm{N}$

- numerals follow the nouns: N NUM

- no alienability contrast in possessive constructions.

\section{Vowels}

\subsection{Overview of the vowel system}

Ngen vowels are arranged in two series, oral and nasal, as shown in Table 1.

Table 1

Phonological inventory of Ngen vowels

\begin{tabular}{|c|c|c|c|c|c|c|c|}
\hline & \multicolumn{3}{|c|}{ Oral } & \multicolumn{3}{|c|}{ Nasal } \\
\hline & & Front & Middle & Back & Front & Middle & Back \\
\hline & High & $\mathrm{i}$ & & $\mathrm{u}$ & $\underset{\sim}{\mathrm{i}}$ & & $\underset{\sim}{\mathrm{u}}$ \\
\hline \multirow{2}{*}{ Mid } & Upper-mid & $\mathrm{e}$ & & 0 & \multirow{2}{*}{$\underset{\sim}{\mathcal{E}}$} & & \multirow{2}{*}{$\underset{2}{2}$} \\
\hline & Lower-mid & $\varepsilon$ & & כ & & & \\
\hline & Low & & a & & & $\underset{\sim}{\mathrm{a}}$ & \\
\hline
\end{tabular}


Upper-mid nasal vowel counterparts to oral vowels do not occur: $* / \mathrm{e} /, * / \mathrm{Q} /$.

Vowels from different series cannot be combined in the same foot

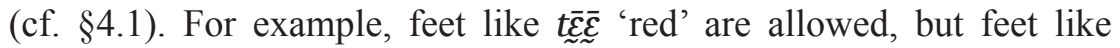
${ }^{*} t \bar{\tau} \bar{\varepsilon}$ are disallowed. /i/ in the first syllable of a foot of the type Cili is reduced to [ì], for example, gìlì [gìlì] 'war', bìlì [bìlì] 'wooden ceiling', bịli [Ǵílì mìnì] 'head', yìrì [ỳ̀rì] 'tree', pî́lì [pínín 'tail'.

Minimal pairs contrasting vowel height (1)-(5) and backness (6)-(8) are shown below.

(1) yì 'to sleep' - yè 'to see' - yà '2sG.PST+'

(2) $s \hat{\varepsilon}$ 'fire' - sí 'to call'

(3) wélé 'bone' - wélé 'problem'

(4) $p \varepsilon$ 'to whistle' - pá 'to bite'

(5) gù 'smith'-gò 'to hide' - g̀̀ 'to pass'- gà 'death'

(6) títí 'often'- tútú 'for a long time'

(7) yè 'to see' - yò 'alcohol'

(8) sć 'fire' - só 'between'

Minimal pairs contrasting oral and nasal vowels are shown in examples (9)-(12).

(9) ká '2PL.BSC+' - káa 'who'

(10) gbílí 'dirty' - gbîlí 'manioc/cassava'

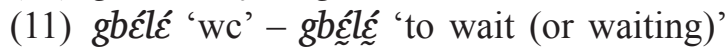

(12) kpóńgbón 'near' - kpহ̃ńgbহ̃ ’́ 'fat'

\subsection{Status of $\boldsymbol{y}$}

In addition to oral and nasal vowels, there is a syllabic nasal $/ \mathfrak{y} /$ or 'zero aperture vowel' (Bearth 1971: 44), which has been identified in other South Mande languages (Perekhvalskaya 2017; Idiatov \& Aplonova 2017) (Aplonova \& Vydrin 2017). The status of $\eta$ is controversial. 
$\eta$ usually appears at the foot-final position in CVy, ClVy, CVVy structures, e.g.: ḡ̄̄j 'man', tróń 'ear', fūán 'copper'. It can bear a tone different from the tone of the preceding vowel, for example, yān 'how much', bōn 'agama'. Moreover, the form of the the first personal pronoun is / $/ \mathfrak{y} /$ [

However, $\eta$ is realised as $[\mathrm{y}]$ before a pause or before another vowel, e.g. wī̄ à $k \bar{\jmath}$ [wī̄ àk̄̄] 'three languages'.

(13) gbóń dō [gbóń dō] 'one baboon'

(14) wī̄ tízì [wīn tízì] 'ten languages'

(15) bōń sóń [bōń sóń] 'six agamas'

(16) gbóń pālā̄̄ [gbóm pālāī] 'two baboons'

(17) lī̄ gó [lī̄̄ gó] 'woman's chest'

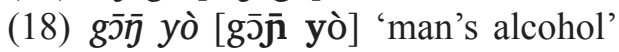

(19) $\bar{\eta} g b \bar{\jmath}[\overline{\mathbf{y}} \mathbf{m b} \bar{\jmath}]$ 'my honey'

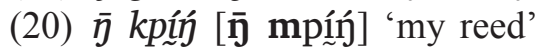

In the data I have at the moment, a word-initial $/ \mathbf{y} /$ is attested in

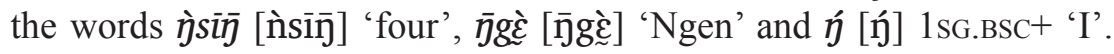
In word-border contexts $/ \mathfrak{y} /$ is assimilated by the place of articulation of the following consonant.

On the one hand, dissimilar tones in $\mathrm{CVy}$-structures and the existence of $\eta^{\prime}$ ' $1 \mathrm{sG} . \mathrm{BSC}^{+}$' are an argument to treat $/ \mathrm{y} /$ as a vowel, but on the other hand, Cy-syllables are not attested and $/ \mathrm{y} /$ is assimilated by the place of articulation of the following consonant, which does not allow to analyze it as a "standard" vowel.

\section{Consonants}

The consonant system distinguishes six places of articulation: labial, dental, palatal, velar, glottal and doubly-articulated labiovelars. Consonant phonemes are represented in Table 2. 
Table 2

Inventory of consonant phonemes

\begin{tabular}{|l|c|c|c|c|c|c|c|}
\hline \multicolumn{2}{|c|}{} & labial & dental & palatal & velar & labiovelar & glottal \\
\hline \multirow{3}{*}{ stops } & $\mathrm{vd}$ & $\mathrm{b}[\mathrm{b} / \mathrm{m}]$ & $\mathrm{d}$ & $\mathrm{f}$ & $\mathrm{g}$ & $\widetilde{\mathrm{gb}}$ & \\
\cline { 2 - 9 } & $\mathrm{vs}$ & $\mathrm{p}$ & $\mathrm{t}$ & & $\mathrm{k}[\mathrm{c}, \mathrm{k}]$ & $\widetilde{\mathrm{kp}}$ & \\
\hline \multirow{2}{*}{ fricatives } & $\mathrm{vd}$ & $\mathrm{v}$ & $\mathrm{z}$ & & & & \\
\cline { 2 - 9 } & $\mathrm{vs}$ & $\mathrm{f}$ & $\mathrm{s}$ & & & & $\mathrm{h}$ \\
\hline \multicolumn{2}{|l|}{ sonorants } & & $1[\mathrm{l} / \mathrm{n}, \mathrm{r}]$ & $\mathrm{j}[\mathrm{j} / \mathrm{j}]$ & & $\mathrm{w}$ & \\
\hline
\end{tabular}

There are several notes about Table 2. First, phonetic realisations of phonemes are given in brackets. Second, allophones contrasted by the feature "oral / nasal" are presented in the same cell, separated by a slash (cf. §5). Third, in what follows, phonemes $/ \widetilde{\mathrm{kp}}, \widehat{\mathrm{gb}} /$ will be written without tie i.e. kp, gb. Finally, the approximant $/ \mathbf{j} /$ is represented as $y$ in what follows, and $j$ stands for the palatal plosive $/ \mathfrak{f} /$.

The lateral [1] and the vibrant $[\mathrm{r} \sim \mathrm{r}]$ are allophones of the same phoneme $/ 1 /$. It is realized only as [1] in foot-initial position, but not as $[r \sim r]$. In foot-internal position in an oral foot the allophones are distributed as follows: $[\mathrm{r} \sim \mathrm{r}]$ after dental and palatal consonants $(21)$ (26), and [1] otherwise (27)-(29).

(21) jàlā [jàrā] 'lion'

(22) jèlè [jèrè] 'hot'

(23) tlóń [tróń] 'ear'

(24) dlá [drá] 'to fall'

(25) sālā [sārā] 'to take'

(26) zūlū̄̄ [zūrūīj] 'driver ant'

(27) pálá [pálá] 'house'

(28) gàlà [gàlà] 'month'

(29) wélé [wélé] 'problem'

The glide /w/ is optionally deleted at morpheme boundaries, especially in function words, e.g. kàlà wō [kàlà ō] 'to put down'. 
Palatal $[\mathrm{c}]$ and velar $[\mathrm{k}]$ are allophones representing one phoneme, $\mathrm{k} /$. [c] appears before front vowels, and [k] before back vowels and middle /a/. For example see (30)-(34).

(30) ké [cÉ] 'house'

(31) $k i \overline{~[c i ̄] ~ ' s k i n, ~ p a p e r ' ~}$

(32) kóń [kóń] 'sorrow'

(33) kóń [kóń] 'crotchet'

(34) kálí [kálí] 'peanut'

On the other hand, palatal $/ \mathrm{j} /$ and velar $/ \mathrm{g} /$ are not allophones, but phonemes, e.g. : jò 'make noise.PST' - gò 'basket'.

Glottal $[\mathrm{h}]$ is attested in two words, $h \bar{a}$ 'hundred', probably borrowed from English 'hundred' (Djonkro village has stable commercial relations with Ghana), and gb̀̀hı̀l’̀ 'heavy'.

\section{Syllable features}

In my analysis of the Ngen syllable, I follow (Bolli 1976) (as cited by (Vydrin 2008)), who postulates two types of syllables: "minor", V, and "major", CV or CCV. A minor syllable can be represented by any vowel (including $\eta$ ), while a major syllable can have any vowel but $\eta$. Any consonant can occupy the initial position in a major syllable, while in the second consonantal position of the CCV syllable, only $l$ is possible. $/ 1 /$ is realised as [r] after initial dental and palatal stops $/ \mathrm{t} /$, /d/, see examples in Table 4 and in (21)-(26).

\section{Feet}

Feet in South Mande languages are defined by Vydrin (2008) as "metric feet", mono- or polymoraic units which have several properties: vowel harmony, restrictions on the internal structure and on the inventory of intervocalic consonants. Feet also can contain several syllables or only one syllable, and such one-syllable-feet are rather numerous. Grammatical 
tones are applied to the metric foot, rather than to a syllable or a mora. Finally, feet exist in languages without stress, for example, Guro (Kuznetsova \& Kuznetsova 2017) or Mano (Khachaturyan 2015).

There are several arguments to postulate feet as the main prosodic (rhythmic) unit of Ngen. First, there is a nasal-oral harmony within the limits of a foot. Second, there is a restriction for front vowels after back vowels in CVCV structures. Third, in Cili feet, initial /i// reduces to $[\mathbf{i}]$. Fourth, phoneme $/ 1 /$ is realised only as [1] in the foot-initial position, but not as $[\mathrm{r} \sim \mathrm{r}]$. In the foot-internal position in oral feet, the allophones are distributed: $[\mathrm{r} \sim \boldsymbol{r}]$ after dental and palatal consonants and [1] otherwise. Fifth, a bigger part of CVIV or CVIVy words in vocabulary has the same tone on both vowels, i.e. gbàlà 'sponge', ká 'to steal', kúlú 'piece', lêेlè̄ 'song', pílí 'tail', póló 'food', etc.

At the present moment, there are not enough data about to check all the criteria of South Mande foot suggested in (Vydrin 2008). Especially tonal data of CVV, CVVy feet and the restrictions on the consonants in the intervocalic position for $\mathrm{CVCV}, \mathrm{C}_{1} \mathrm{VC}_{2} \mathrm{~V}$ feet.

In what follows, $\mathrm{C}$ stands for any consonant except $/ 1 /, l$ stands for the consonant $/ 1 /, \mathrm{V}$ is any vowel, and $\eta$ is a foot-final nasal. Feet in Ngen consist of the prosodic types shown in Table 3.

Table 3

Foot structures

\begin{tabular}{|c|c|}
\hline Foot structures & Examples \\
\hline $\mathrm{V}$ & è '3SG.BSC+', à '3sG.POSS' \\
\hline $\mathrm{CV}$ & bà 'rope', fरे 'wind' \\
\hline CVV & gíè 'good', p̄̄ó 'field', gāé 'corpse' \\
\hline $\mathrm{CVy}$ & $b \bar{a} \bar{\eta}$ 'ground', sśń 'tooth' \\
\hline CVVy & píóý 'arrow head', fúáń 'alluminium' \\
\hline $\mathrm{ClV}$ & tré 'yams', zlà 'spouse' \\
\hline $\mathrm{ClVy}$ & tróń 'ear', dríñ 'tomorrow' \\
\hline CVlVy & $l \bar{\varepsilon} l \bar{\varepsilon} \bar{\eta}$ 'song', pālā̄̄ ‘two' \\
\hline CVIV & gōlì 'cola nut', kálá 'to steal' \\
\hline
\end{tabular}




\section{Word structure}

Most of the words in my dictionary (containing $\sim 850$ items) represent $\mathrm{CV}, \mathrm{CVCV}, \mathrm{CVy}$ structures. Structures of V, VCV-type ${ }^{1}$ are not frequent, in comparison to neighbouring Beng and $G b a n . \mathrm{CV}_{1} \mathrm{~V}_{1}$ g structures are not attested, and vowels in CVVy structures are never identical. There are /a/, /e/ in the syllable of the $\mathrm{V}$ type, but not $/ \mathrm{u} /, / \mathrm{o} /, / \mathrm{o} /, / \varepsilon /$, e.g.: àkễllèwwā 'spider', èbúbú 'bright'. CVlV structures often have two similar vowels and tones, e.g.: gàlà 'month', pálá 'house', wúlú 'ghost', bilì 'parcel of forest', mìl lì 'chicken'.

In the data I have at the moment, there is a restriction: back vowels cannot follow front vowels in the same word, i.e. words like *bibu are disallowed. Only 7 lexemes from $\sim 850$ contradict this restriction: $p \grave{\varepsilon} l \bar{o}$ 'to jump', tiótió 'scissors', bèwō 'to dance', dèú 'wild cat', píón 'sharp', yīpú 'sun'.

\section{Nasal harmony}

The feature of nasality is associated with all phonemes of a foot, including the consonants, but excluding $\eta$ which is not subject to nasal harmony (it can combine with nasal and oral elements). Nasal consonants have no phonological status in Ngen, these are allophones of their oral counterparts. This phenomenon is typical of South Mande languages (this interpretation was advanced for the first time by Le Saout (1973)).

As shown in Table 4, three approximants and one stop have nasal and oral allophones. The choice of a nasal or an oral allophone depends on the vowel type in the foot: there are nasal allophones for nasal vowels and oral variants for oral vowels. For example, bili [Gìlì mìnì] 'head' has various phonetic realisations; it provides evidence for nasal and oral sonants to be allophones. It is important to stress that a foot, but not a word or syllable is the main domain of nasalization.

${ }^{1}$ These lexemes are likely borrowings from the Ando dialect of Baule. 
Feet with oral sonants and nasalized vowels (such as *[la $]$ * $[\mathrm{ba}]$, *[ya], *[na], *[ma], *[na]) are not attested. Oral and nasal allophones are represented in Table 4.

Table 4

Oral and nasal allophones of consonants

\begin{tabular}{|c|c|c|}
\hline Phoneme & $\begin{array}{c}\text { Phonetic realization } \\
\text { without nasalisation }\end{array}$ & $\begin{array}{l}\text { Phonetic realization } \\
\text { with nasalisation }\end{array}$ \\
\hline /b/ & {$[\mathrm{b}]$} & {$[\mathrm{m}]$} \\
\hline$/ \mathrm{l} /$ & {$[\mathrm{l}]$} & {$[\mathrm{n}]$} \\
\hline$/ \mathrm{y} /$ & {$[\mathrm{y}]$} & {$[\mathrm{n}]$} \\
\hline$/ \mathrm{w} /$ & {$[\mathrm{w}]$} & {$[\mathrm{y}]$} \\
\hline
\end{tabular}

In the current version of the Ngen-English dictionary, the initial

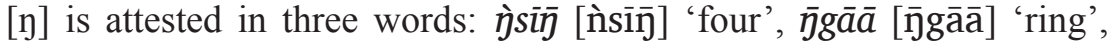

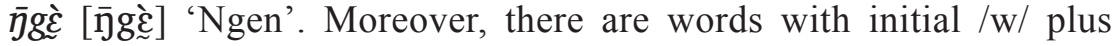

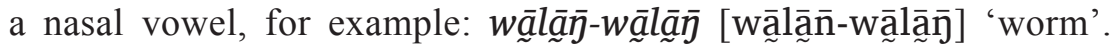
Thus, contrary to expectations, the $/ \mathrm{w} /$ phoneme does not has an allophone [y] at the present moment. To sum up, phonemes /b/, /l/, /y/ have two allophones each: nasal and non-nasal. /w/ has no nasal allophone.

\section{Tone}

Ngen has 3 level tones, shown in Table 5. Stress has not been observed.

Table 5

Examples for tonal contrasts

\begin{tabular}{|l|c|l|l|}
\hline Tone & Notation & \multicolumn{3}{|l|}{ Example } \\
\hline High & á & dó 'termite' & báý 'sheep' \\
\hline Middle & $\bar{a}$ & dō 'one' & bā̄̄y 'ground' \\
\hline Low & à & dò 'cobra' & bà̀̀ 'wing' \\
\hline
\end{tabular}


It is assumed in this paper that the basic tone-bearing unit (TBU) is a single vowel (including $\eta$ ) or 'minor syllable', but a 'major' one, because sequences of two vowels CVV in major syllables can bear either similar or dissimilar tones e.g.: sùà 'money', tāá 'pothole', giè 'good'.

Melodies at the word level are diverse. A few observations can be shown here. Tone melodies on disyllabic feet exhibit all possible combinations except LH, as shown in Table 6.

Table 6

\section{Diversity of tone melodies on CVCV structures}

\begin{tabular}{|c|c|c|}
\hline Melody & Ngen & Gloss \\
\hline $\mathrm{HH}$ & básá & 'other' \\
\hline $\mathrm{MM}$ & $g \bar{l} l i$ & 'cola nut' \\
\hline LL & nָِ & 'star' \\
\hline HM & dádā & 'to suck' \\
\hline $\mathrm{HL}$ & jén£̃ & 'onion' \\
\hline MH & bōló & 'maize' \\
\hline ML & kِّ̄ñà & 'crocodile' \\
\hline LM & $k \grave{\varepsilon} t \bar{\varepsilon}$ & 'mat' \\
\hline
\end{tabular}

\section{Conclusion}

Ngen is a typical South Mande language. It has 2 series of vowels, oral and nasal. There is a consonant inventory typical to the South Mande group with one special feature, which is the absence of implosive consonant phonemes. The consonant inventory is marked by a complementary distribution between [b] and [m], [1] and [n], [y] and [n]. There is evidence of nasal harmony. There are 3 level tones. Tone melodies on disyllabic feet exhibit all possible combinations except LH. Most of the non-derived words have CV, CVCV, CVy structures. 


\section{Abbreviations}

+- affirmative polarity series

Aux - auxiliary verb

$\mathrm{C}$ - consonant

$\mathrm{BSC}-$ basic series of pronouns

$\mathrm{O}$ - object

POSS - posessive series of pronouns
PST - past series of pronouns

PL - plural

$\mathrm{S}$ - subject

$\mathrm{SG}$ - singular

TBU - tone-bearing unit

$\mathrm{V}-$ vowel or verb

\section{Acknowledgements}

The research was conducted in terms of the project supported by Russian Science Foundation, grant No. 17-78-20071 fulfilled in the Institute of Linguistics, Russian Academy of Sciences.

I express my sincere gratitude to my Ngen consultants Kouassi Makaman Koffi (Sualio Wattara) and Kouadio Kouadio Yacouba, as well as to Valentin Vydrin who has supervised my research.

\section{References}

Aplonova, Ekaterina \& Vydrin, Valentin. 2017. Goo jazyk [The Goo language]. In Vydrin, Valentin \& Mazurova, Yulia \& Kibrik, Andrej A. \& Markus, Elena (eds.), Jazyki mira: jazyki mande [Languages of the world: Mande languages], 457-469. St. Petersburg: Nestor-Istorija.

Bearth, Thomas. 1971. L'énoncé toura (Côte d'Ivoire). Norman: Oklahoma University.

Bolli, Margrit. 1976. Etude prosodique du Dan (Blossé). Abidjan: Institut de linguistique appliquée - Société Internationale de Linguistique. (Publications conjointes ILA-SIL 1.)

Idiatov, Dmitry \& Aplonova, Ekaterina. 2017. Tura jazyk [The Tura language]. In Vydrin, Valentin \& Mazurova, Yulia \& Kibrik, Andrej A. \& Markus, Elena (eds.), Jazyki mira: jazyki mande [Languages of the world: Mande languages], 583-616. St. Petersburg: Nestor-Istorija.

Khachaturyan, Maria. 2015. Grammaire du mano. Mandenkan. Bulletin semestriel d'études linguistiques mandé 54. 1-252.

Kuznetsova, Natalia \& Kuznetsova, Olga. 2017. Guro jazyk [The Guro language]. In Vydrin, Valentin \& Mazurova, Yulia \& Kibrik, Andrej A. 
\& Markus, Elena (eds.), Jazyki mira: jazyki mande [Languages of the world: Mande languages], 765-877. St. Petersburg: Nestor-Istorija.

Le Saout, Joseph. 1973. Langues sans consonnes nasales. Annales de l'Université d'Abidjan (Linguistique) 6(1). 179-205.

Maloletnjaja, Anna. 2015. Èlementy opisanija jazyka ngen [Elements of Ngen description]. Moscow: Higher School of Economics. (B.A. thesis.)

Paperno, Denis. 2014. Grammatical sketch of Beng. Mandenkan. Bulletin semestriel d'études linguistiques mandé 51. 1-130.

Perekhvalskaya, Elena. 2017. Muan jazyk [The Mwan language]. In Vydrin, Valentin \& Mazurova, Yulia \& Kibrik, Andrej A. \& Markus, Elena (eds.), Jazyki mira: jazyki mande [Languages of the world: Mande languages], 718-765. St. Petersburg: Nestor-Istorija.

Vydrin, Valentin. 2008. Metričeskaja stopa v jazykax mande [Metric foot in Mande languages]. In Arkhipov, Alexander \& Zakharov, Leonid \& Kibrik, Andrej \& Kibrik, Alexander \& Kobozeva, Irina \& Krivnova, Olga \& Lyutikova, Ekaterina \& Fedorova, Olga (eds.), Fonetika i nefonetika. K 70-letiju Sandro Vasil 'eviča Kodzasova [Phonetics and non-phonetics. To the 70th anniversary of Sandro V. Kodzasov], 308-317. Moscow: Jazyki slavjanskix kul'tur. 